\title{
Spices in the Apiaceae Family Represent the Healthiest Fatty Acid Profile: A Systematic Comparison of 34 Widely Used Spices and Herbs
}

\author{
Ramesh Kumar Saini ${ }^{1}$ (D), Awraris Derbie Assefa ${ }^{2}$ and Young-Soo Keum ${ }^{1, *}$ \\ 1 Department of Crop Science, Konkuk University, Seoul 05029, Korea; saini1997@konkuk.ac.kr \\ 2 National Agrobiodiversity Center, National Institute of Agricultural Sciences, \\ Rural Development Administration, Jeonju 54874, Korea; awraris@korea.kr \\ * Correspondence: rational@konkuk.ac.kr
}

\section{check for}

updates

Citation: Saini, R.K.; Assefa, A.D.; Keum, Y.-S. Spices in the Apiaceae Family Represent the Healthiest Fatty Acid Profile: A Systematic Comparison of 34 Widely Used Spices and Herbs. Foods 2021, 10, 854. https: / / doi.org/10.3390/ foods10040854

Academic Editors:

Andreas Eisenreich and Bernd Schaefer

Received: 8 March 2021

Accepted: 12 April 2021

Published: 14 April 2021

Publisher's Note: MDPI stays neutral with regard to jurisdictional claims in published maps and institutional affiliations.

Copyright: (c) 2021 by the authors. Licensee MDPI, Basel, Switzerland. This article is an open access article distributed under the terms and conditions of the Creative Commons Attribution (CC BY) license (https:// creativecommons.org/licenses/by/ $4.0 /)$.

\begin{abstract}
Spices and herbs are well-known for being rich in healthy bioactive metabolites. In recent years, interest in the fatty acid composition of different foods has greatly increased. Thus, the present study was designed to characterize the fatty acid composition of 34 widely used spices and herbs. Utilizing gas chromatography (GC) flame ionization detection (FID) and GC mass spectrometry (MS), we identified and quantified 18 fatty acids. This showed a significant variation among the studied spices and herbs. In general, oleic and linoleic acid dominate in seed spices, whereas palmitic, stearic, oleic, linoleic, and $\alpha$-linolenic acids are the major constituents of herbs. Among the studied spices and herbs, the ratio of $n-6 / n-3$ polyunsaturated fatty acids (PUFAs) was recorded to be in the range of 0.36 (oregano) to 85.99 (cumin), whereas the ratio of PUFAs/saturated fatty acids (SFAs) ranged from 0.17 (nutmeg) to 4.90 (cumin). Cumin, coriander, fennel, and dill seeds represent the healthiest fatty acid profile, based upon fat quality indices such as the ratio of hypocholesterolemic/hypercholesterolemic $(\mathrm{h} / \mathrm{H})$ fatty acids, the atherogenic index $(\mathrm{AI})$, and the thrombogenic index (TI). All these seed spices belong to the Apiaceae family of plants, which are an exceptionally rich source of monounsaturated fatty acids (MUFAs) in the form of petroselinic acid (C18:1n12), with a very small amount of SFAs.
\end{abstract}

Keywords: polyunsaturated fatty acids (PUFAs); erucic acid; petroselinic acid; fat quality indices; hypocholesterolemic fatty acids; atherogenic index (AI)

\section{Introduction}

Spices and herbs are a vital part of human nutrition around the world, especially in India, China, and southeastern Asian countries [1]. Spices and herbs are food adjuncts, traditionally used as flavoring, seasoning, coloring, and as a food preservative agent [1,2]. Moreover, spices and herbs are an exceptionally rich source of nutritionally important phenolic compounds [3]. These phenolic compounds are primarily responsible for the potent antioxidative, digestive stimulative, hypolipidemic, antibacterial, anti-inflammatory, antiviral, and anticancer properties of spices and herbs [4-6].

In general, the terms herbs and spices have more than one meaning. However, the most widely used are those that consider herbs to be derived from the green parts of a plant, such as a stem and leaves used in small amounts to impart flavor, whereas spices are obtained from seeds, buds, fruits, roots, or even the bark of the plants [2].

Fatty acids are the primary nutritional components found in edible seed oils [7]. Seed oils provide essential polyunsaturated fatty acids, linoleic acid $(\omega-6$ or $n-6)$, and $\alpha$-linolenic acid $(n-3)$ to humans and other higher animals. In the human body, linoleic acid give rise to $n-6$ very long-chain (VLC)-PUFA arachidonic acid, and $\alpha$-linolenic acid converts to $n-3$ VLC-PUFA eicosapentaenoic acid (EPA), and docosahexaenoic acid (DHA, 
$n-3)$. These $n-6$ and $n-3$ VLC-PUFAs plays key distinct roles in regulating body homeostasis. In general, $n-6$ VLC-PUFAs gives rise to proinflammatory mediators (eicosanoids) whereas $n-3$ VLC-PUFAs give rise to anti-inflammatory mediators. Thus, a higher amount of $n-3$ VLC-PUFAs in the body may protect from chronic diseases, including cancer, inflammatory, or cardiovascular diseases (CVD) [8]. Moreover, a diet with a high proportion of $n-6$ PUFAs (high ratio of $n-6 / n-3$ PUFAs) cannot be considered beneficial to health, as $n-3$ PUFAs to $n-3$ VLC-PUFAs conversion occurs at a very low rate (e.g., $8 \%$ for EPA and less than $1 \%$ for DHA), and conversion is largely dependent upon the ratio of ingested $n-6$ (linoleic acid) and $n-3$ ( $\alpha$-linolenic) PUFAs [9]. In human hepatoma cells, this conversion is highest when these $n-6$ and $n-3$ acids are provided at a 1:1 ratio. Thus, the consumption of an appropriate amount of fats with a 1:1 n-6/n-3 PUFAs ratio, which was probably followed by our ancestors [10], may be considered beneficial.

Similar to the consumption of fats with a balanced ratio of $n-6 / n-3$ PUFAs, growing evidence suggests that replacing saturated fatty acids (SFAs) with monounsaturated fatty acids (MUFAs) from plant sources may decrease the risk of CVD [11]. And with the health benefits associated with consumption of $n-3$ PUFAs and MUFAs, consumer interest is shifting towards foods with a low proportion of SFAs, a high proportion of MUFAs, and balanced $n-6 / n-3$ PUFAs. Given this, it is necessary to characterize all the major and minor components of the diet to acquire a better estimate of the fatty acid composition of our food.

Spices and herbs are not a significant source of fatty acids, as they form a small part of the diet. However, a detailed and comparative study of the fatty acid composition of various spices and herbs may be useful to identify those with health-beneficial fatty acids. Considering these facts, this study aims to investigate the fatty acid composition of commercially available major spices and herbs utilizing gas chromatography-flame ionization detection and GC-mass spectrometry analysis. We used fatty acid composition data to study spices and herbs to determine their fat quality indices. We anticipate the results contained herein will contribute significantly to the identification of spices with a healthy fatty acid profile.

\section{Materials and Methods}

\subsection{Plant Material, Reagents, and Standards}

A total of 34 commercially packed spices and herbs (Table $1 ; 200-500$ g each spice and herb from at least three different brands) were obtained from retail outlets in Seoul, Korea. The spice and herb samples of different brands were mixed in equal proportions (200-300 g total) to make a representative sample, ground into a fine powder using a 7010HG laboratory blender (Waring Commercial, Torrington, CT, USA), placed into an airtight container, and stored at room temperature. The fatty acid standard mix (37 Component FAME Mix, CRM47885) was obtained from Merck Ltd., Seoul, Korea. The organic solvents used for the extraction of lipids were of high-pressure liquid chromatography (HPLC) grade, obtained from Samchun Chemical Co., Ltd., Seoul, Korea.

\subsection{Extraction of Crude Lipid Compounds}

The crude lipids were extracted by using the previous method $[12,13]$ with minor modification. Briefly, $0.6 \mathrm{~g}$ dehydrated and powdered spices and herb samples were precisely weighed and transferred to a $50 \mathrm{~mL}$ glass tube. In each tube, $150 \mathrm{mg}$ sodium ascorbate and $22 \mathrm{~mL}$ (isopropyl alcohol/cyclohexane, 10:12, $v / v$ ) containing $0.075 \%$ butylated hydroxytoluene (BHT: $w / v$; antioxidant) were added, and the contents were subjected to bath sonication (JAC-2010; $300 \mathrm{w}, 60 \mathrm{~Hz}$, for $12 \mathrm{~min}$ ) for efficient disintegration and complete extraction, followed by $15 \mathrm{~h}$ shaking $\left(200 \mathrm{RPM}\right.$ at $\left.22{ }^{\circ} \mathrm{C}\right)$ in a rotary shaker. Contents were centrifuged at $7000 \times g\left(12 \mathrm{~min}\right.$ at $\left.4^{\circ} \mathrm{C}\right)$. The supernatant was collected, and pellets were extracted again with $30 \mathrm{~mL}$ cyclohexane. Supernatants from both extractions were pooled (total volume of $\sim 50 \mathrm{~mL}$ ) and partitioned with an equal volume of $1 \mathrm{M}$ of sodium chloride $(\mathrm{NaCl})$. The upper cyclohexane phase containing crude lipids were collected, 
filtered over anhydrous sodium sulfate, transferred to a 250-mL round-bottom flask, and vacuum-dried in a rotary evaporator at $30^{\circ} \mathrm{C}$. The crude lipids were recovered into $3 \mathrm{~mL}$ methanol/dichloromethane (DCM) $(1: 3, v / v)$ containing $0.1 \%$ BHT, transferred to a $5 \mathrm{~mL}$ glass vial fitted with a Teflon-lined screw cap, and stored at $-20^{\circ} \mathrm{C}$. One milliliter of sample was used to prepare fatty acid methyl esters (FAMEs).

Table 1. List of spices and herbs used in the present investigation (arranged according to botanical name).

\begin{tabular}{|c|c|c|c|c|}
\hline Sample No. & Common Name & Botanical Name & Family & Part \\
\hline 1 & Galangal root & Alpinia galanga (L.) Willd. & Zingiberaceae & Rhizomes \\
\hline 2 & Dill & Anethum graveolens L. & Apiaceae & Seeds \\
\hline 3 & Celery & Apium graveolens $\mathrm{L}$. & Apiaceae & Seeds \\
\hline 4 & Tarragon & Artemisia dracunculus L. & Asteraceae & Leaves \\
\hline 5 & Cayenne pepper & Capsicum annuum L. & Solanaceae & Pods \\
\hline 6 & Pepperoncini & Capsicum annuum L. var. annuum & Solanaceae & Pods \\
\hline 7 & Hot chili pepper & Capsicum frutescens L. & Solanaceae & Pods \\
\hline 8 & Caraway & Carum carvi $\mathrm{L}$. & Apiaceae & Fruits \\
\hline 9 & Cinnamon & Cinnamomum verum J.Presl & Lauraceae & Bark \\
\hline 10 & Coriander seed & Coriandrum sativum L. & Apiaceae & Seeds \\
\hline 11 & Cumin & Cuminum cyminum L. & Apiaceae & Seeds \\
\hline 12 & Turmeric & Curcuma longa $\mathrm{L}$. & Zingiberaceae & Rhizomes \\
\hline 13 & Lemongrass & Cymbopogon microstachys (J. D. Hooker) Soenarko & Poaceae & Leaves \\
\hline 14 & Cardamom & Elettaria cardamomum (L.) Maton & Zingiberaceae & Pods \\
\hline 15 & Fennel & Foeniculum vulgare Mill. & Apiaceae & Seeds \\
\hline 16 & Star anise & Illicium verum Hook.f. & Schisandraceae & Fruits \\
\hline 17 & Allspice & Pimenta dioica (L.) Merr. & Myrtaceae & Fruits \\
\hline 18 & Juniper berry & Juniperus communis L. & Cupressaceae & Fruits \\
\hline 19 & Bay leaf & Laurus nobilis L. & Lauraceae & Leaves \\
\hline 20 & Nutmeg & Myristica fragrans Houtt. & Myrtaceae & Seeds \\
\hline 21 & Mace & Myristica fragrans Houtt. & Myrtaceae & Aril \\
\hline 22 & Basil & Ocimum basilicum L. & Lamiaceae & Leaves \\
\hline 23 & Marjoram & Origanum majorana L. & Lamiaceae & Leaves \\
\hline 24 & Oregano & Origanum vulgare L. & Lamiaceae & Leaves \\
\hline 25 & Parsley & Petroselinum crispum (Mill.) Fuss & Apiaceae & Leaves \\
\hline 26 & Black pepper & Piper nigrum L. & Piperaceae & Fruits (unripe) \\
\hline 27 & White pepper & Piper nigrum $\mathrm{L}$. & Piperaceae & Seeds \\
\hline 28 & Rosemary & Rosmarinus officinalis L. & Lamiaceae & Leaves \\
\hline 29 & Sage & Salvia officinalis L. & Lamiaceae & Leaves \\
\hline 30 & Pink peppercorn & Schinus mole L. & Anacardiaceae & Fruits \\
\hline 31 & White mustard & Sinapis alba L. & Brassicaceae & Seeds \\
\hline 32 & Clove & Syzygium aromaticum (L.) Merr. and L. M. Perry & Myrtaceae & Flower buds \\
\hline 33 & Thyme & Thymus vulgaris L. & Lamiaceae & Leaves \\
\hline 34 & Ginger & Zingiber officinale Roscoe & Zingiberaceae & Rhizomes \\
\hline
\end{tabular}

\subsection{Preparation of Fatty Acid Methyl Esters (FAMEs)}

The crude lipids extracted from the spices and herb samples were used to prepare the FAMEs, following the previously optimized method [14] with minor modification. Briefly, $1 \mathrm{~mL}$ of a crude lipids sample was transferred into a $5 \mathrm{~mL}$ glass vial fitted with a Teflon-lined screw cap. Contents were evaporated to dryness using a rotary evaporator at $30{ }^{\circ} \mathrm{C}$. After evaporation, $3 \mathrm{~mL}$ of anhydrous methanolic- $\mathrm{HCl}$ (methanol/acetyl chloride, 95:5, $v / v$ ) was added and incubated for $2 \mathrm{~h}$ at $55^{\circ} \mathrm{C}$ in a heat block. Samples were cooled in ice, and FAMEs were sequentially washed with $1 \mathrm{M} \mathrm{NaCl}$ and $2 \%$ sodium bicarbonate $\left(\mathrm{NaHCO}_{3}\right)$ and recovered in $4 \mathrm{~mL}$ hexane. A pinch of anhydrous sodium sulfate $\left(\mathrm{Na}_{2} \mathrm{SO}_{4}\right)$ was added to the recovered sample (hexane) to absorb the traces of water. One milliliter of sample was filtered through a $0.45 \mu \mathrm{m}$ PTFE syringe filter and transferred to a $1.5 \mathrm{~mL}$ autosampler vial for GC-FID and GC-MS analysis. 


\subsection{GC-FID and GC-MS Analysis of FAMEs}

FAMEs were quantitatively analyzed with GC (Agilent 7890B, Agilent Technologies Canada, Inc., Mississauga, ON, Canada) equipped with an autoinjector, an FID, and an SP-2560 capillary column (100 m, $0.20 \mu \mathrm{m}$ film thickness, $0.25 \mathrm{~mm}$ ID; Merck KGaA, Darmstadt, Germany). The injector and the detectors were maintained at $250{ }^{\circ} \mathrm{C}$ and $260^{\circ} \mathrm{C}$, respectively. The inlet flow was $2 \mathrm{~mL} / \mathrm{min}$ with a constant pressure of $54 \mathrm{psi}$. The FID parameters of hydrogen $\left(\mathrm{H}_{2}\right)$ fuel flow, airflow, and make flow (nitrogen, $\mathrm{N}_{2}$ ) were set to 30,400 , and $25 \mathrm{~mL} / \mathrm{min}$, respectively. The column oven temperature was kept at $140{ }^{\circ} \mathrm{C}$ for $5 \mathrm{~min}$, then progressively increased to $240^{\circ} \mathrm{C}$ for $25 \mathrm{~min}$ (linear temperature program $4{ }^{\circ} \mathrm{C} / \mathrm{min}$ and held at $240{ }^{\circ} \mathrm{C}$ for $15 \mathrm{~min}$ [15]. The FAMEs were precisely identified by comparing them with the retention time with authentic standards. For a more accurate qualitative analysis, the mass spectra were also recorded using a GC-MS system (QP2010 SE; Shimadzu, Kyoto, Japan), following the optimized GC-FID analysis thermal program. The identity of FAMEs was confirmed by comparing their fragmentation pattern with authentic standards, and also by using the National Institute of Standards and Technology (NIST; U.S. Department of Commerce, Gaithersburg, MD, USA) mass spectrum database (NIST08 and NIST08s).

\subsection{Calculation of Fat Quality Indices}

We used the spice and herbs fatty acid profile to determine several nutritional parameters of lipids, including the ratios of PUFAs/monounsaturated fatty acids (MUFAs), PUFAs/saturated fatty acids (SFAs), the ratio of hypocholesterolemic/hypercholesterolemic $(\mathrm{h} / \mathrm{H})$ fatty acids, atherogenic index (AI), and thrombogenic index (TI) [16]. The ratio of $\mathrm{h} / \mathrm{H}$ fatty acids, $\mathrm{AI}$, and TI was calculated with the following equations [16]:

$$
\begin{aligned}
& \mathrm{h} / \mathrm{H}=\frac{\text { cis } \mathrm{C} 18: 1+\sum \text { MUFAs }+\sum \text { PUFAs }}{\mathrm{C} 12: 0+\mathrm{C} 14: 0+\mathrm{C} 16: 0} \\
& \mathrm{AI}=\frac{\mathrm{C} 12: 0+(4 \times \mathrm{C} 14: 0)+\mathrm{C} 16: 0}{\sum \text { MUFAs }+\sum \text { PUFAs }} \\
& \mathrm{TI}=\frac{\mathrm{C} 14: 0+\mathrm{C} 16: 0+\mathrm{C} 18: 0}{\left(0.5 \times \sum \text { MUFAs }\right)+\left(0.5 \times \sum n-6 \text { PUFAs }\right)+\left(3 \times \sum n-3 \text { PUFAs }\right)+\left(\frac{\sum n-3 \text { PUFAs }}{\sum n-6 \text { PUFAs }}\right)}
\end{aligned}
$$

\subsection{Statistical Analysis and Quality Control}

We performed a total of six replicate extractions and analyses from each representative sample. The data were analyzed by one-way analysis of variance (ANOVA), and homogenous subsets (mean separation) were determined using Turkey HSD with a significance level of $p<0.05$, utilizing the IBM statistical 25.0 software.

The method used for GC-FID quantification of FAMEs was validated recently [15].

\section{Results and Discussion}

\subsection{Fatty Acids Composition}

In the present study, 18 fatty acids were identified and quantified, utilizing GC-FID and GC-MS analyses (Table 2). The results, given in Table 2, show that oleic (C18:1n9) and linoleic acid (C18:2n6) are dominated in seed spices, and palmitic (C16:0), stearic, oleic, linoleic, and $\alpha$-linolenic acid (C18:3n 3$)$ are the major constituents of herbs. An exception was myristic (C14:0) acid, which was $60.8 \%$ of total fatty acids in Myristica fragrans (nutmeg) seeds (Figure 1A,B). Surprisingly, myristic acid was just $1.59 \%$ of the total fatty acids in the $M$. fragrans (mace; Figure 1C) seed arils. The highest proportions of oleic acid (41.64-41.85\%) were recorded in cardamon pods/capsules (Figure S1) and white pepper seeds (Table 2). The data of the fatty acid composition of cardamom pods and white pepper seeds are scarce. However, $40.6-49.2 \%$ of oleic acid has been reportedly extracted from cold-pressed cardamom seeds $[17,18]$, which agrees with data obtained in the present study from whole cardamon pods. 
Table 2. Fatty acid composition of spices and herbs.

\begin{tabular}{|c|c|c|c|c|c|c|c|c|c|c|c|c|c|c|c|c|c|c|}
\hline Peak No & 1 & 2 & 3 & 4 & 5 & 6 & 7 & 8 & 9 & 10 & 11 & 12 & 13 & 14 & 15 & 16 & 17 & 18 \\
\hline $\begin{array}{l}\text { Component } \\
\text { (FAME) }\end{array}$ & $\begin{array}{c}\text { C12:0 } \\
\text { (Lauric) }\end{array}$ & $\begin{array}{c}\text { C14:0 } \\
\text { (Myristic) }\end{array}$ & $\begin{array}{l}\text { C15:0 } \\
\text { (Pentade- } \\
\text { canoic) }\end{array}$ & $\begin{array}{l}\text { C16:0 } \\
\text { (Palmitic) }\end{array}$ & $\begin{array}{l}\text { C16:1 } \\
\text { (Palmi- } \\
\text { toleic) }\end{array}$ & $\begin{array}{c}\text { C17:0 } \\
\text { (Heptade- } \\
\text { canoic) }\end{array}$ & $\begin{array}{c}\text { C18:0 } \\
\text { (Stearic) }\end{array}$ & $\begin{array}{l}\mathrm{C} 18: 1 \mathrm{n} 12 \mathrm{c} \\
\text { (Pet- } \\
\text { roselinic) }\end{array}$ & $\begin{array}{l}\text { C18:1n9c } \\
\text { (Oleic) }\end{array}$ & $\begin{array}{c}\text { C16:3n3 } \\
\text { (Hexade- } \\
\text { catrienoic) }\end{array}$ & $\begin{array}{l}\text { C18:2n6c } \\
\text { (Linoleic) }\end{array}$ & $\begin{array}{l}\text { C20:0 } \\
\text { (Arachidic) }\end{array}$ & $\begin{array}{c}20: 1 \mathrm{n} 9 \\
\text { (Eicosenoic) }\end{array}$ & $\begin{array}{c}\text { C18:3n3 } \\
(\alpha- \\
\text { Linolenic) }\end{array}$ & $\begin{array}{c}\text { C22:0 } \\
\text { (Be- } \\
\text { henic) }\end{array}$ & $\begin{array}{l}\text { C22:1n9 } \\
\text { (Erucic) }\end{array}$ & $\begin{array}{l}\text { C24:0 } \\
\text { (Ligno- } \\
\text { ceric) }\end{array}$ & $\begin{array}{l}\text { C24:1n9 } \\
\text { (Ner- } \\
\text { vonic) }\end{array}$ \\
\hline RT & 13.44 & 16.78 & 18.58 & 20.42 & 21.74 & 22.20 & 23.96 & 25.03 & 25.10 & 25.20 & 26.81 & 27.29 & 28.36 & 28.60 & 30.38 & 31.48 & 33.46 & 34.57 \\
\hline S1 & 0.62 & 0.90 & $1.18^{\mathrm{a}}$ & 37.65 & nd & nd & 13.06 & nd & 28.21 & nd & 13.59 & nd & nd & 2.45 & 1.01 & nd & 1.33 & nd \\
\hline S2 & 1.20 & 0.90 & nd & 8.48 & 0.34 & nd & 1.54 & 50.37 & 15.26 & nd & 20.49 & 0.23 & nd & 0.85 & 0.23 & nd & 0.12 & nd \\
\hline S3 & nd & 0.44 & nd & 11.09 & 0.21 & nd & 1.91 & 49.42 & 7.48 & nd & 27.55 & 0.23 & nd & 1.32 & 0.21 & nd & 0.15 & nd \\
\hline S4 & 6.95 & 2.90 & nd & 24.86 & nd & nd & 3.03 & nd & 2.23 & nd & 24.10 & 2.21 & nd & 31.84 & 1.16 & nd & 0.72 & nd \\
\hline S5 & 0.27 & 0.95 & nd & 18.25 & 0.64 & 0.13 & 2.73 & nd & 12.31 & nd & 61.46 & 0.38 & nd & 2.53 & 0.22 & nd & 0.12 & nd \\
\hline S6 & 0.27 & 1.19 & nd & 18.71 & 0.86 & nd & 3.03 & nd & 12.68 & nd & 59.65 & 0.45 & nd & 2.75 & 0.27 & nd & 0.16 & nd \\
\hline S7 & 1.18 & 3.22 & nd & 21.98 & 0.85 & nd & 3.87 & 21.76 & 17.43 & nd & 27.99 & 0.48 & nd & 0.68 & 0.36 & nd & 0.20 & nd \\
\hline S9 & $\mathrm{Nd}$ & 1.77 & nd & 33.97 & nd & nd & 7.49 & nd & 23.25 & nd & 26.99 & nd & nd & 4.04 & 1.13 & nd & 1.36 & nd \\
\hline S10 & 0.10 & 0.45 & 0.14 & 6.91 & 0.28 & nd & 1.36 & 62.07 & 7.13 & nd & 20.85 & nd & nd & 0.35 & 0.23 & nd & 0.12 & nd \\
\hline S11 & 0.08 & 0.10 & 0.16 & 5.28 & 0.29 & nd & 1.08 & 49.89 & 9.21 & nd & 33.34 & nd & nd & 0.39 & 0.12 & nd & 0.07 & nd \\
\hline S12 & 2.81 & 0.40 & nd & 10.51 & 0.76 & nd & 2.67 & nd & 4.48 & nd & $72.86^{\mathrm{a}}$ & nd & nd & 4.50 & 0.32 & nd & 0.67 & nd \\
\hline S13 & 5.68 & 2.74 & nd & $47.82^{\mathrm{a}}$ & nd & nd & 9.46 & nd & 6.20 & nd & 12.29 & 3.89 & nd & 5.70 & $3.64^{\mathrm{a}}$ & nd & 2.57 & nd \\
\hline S14 & nd & 0.75 & nd & 32.84 & $1.58^{\mathrm{a}}$ & nd & 3.19 & nd & $41.81^{\mathrm{a}}$ & nd & 15.07 & 0.67 & nd & 3.44 & 0.26 & nd & 0.38 & nd \\
\hline S15 & 0.46 & 0.17 & nd & 7.25 & 0.21 & nd & 1.24 & $63.33^{\mathrm{a}}$ & 6.88 & nd & 19.60 & 0.16 & nd & 0.53 & 0.10 & nd & 0.07 & nd \\
\hline S16 & 1.47 & 0.26 & nd & 20.26 & 0.17 & nd & 3.74 & nd & 33.75 & nd & 39.27 & nd & nd & 0.71 & 0.29 & nd & 0.08 & nd \\
\hline S17 & nd & 0.29 & nd & 14.27 & nd & $0.21^{\mathrm{a}}$ & $27.16^{\mathrm{a}}$ & nd & 13.90 & nd & 39.58 & 1.39 & nd & 2.53 & 0.47 & nd & 0.20 & nd \\
\hline $\mathrm{S} 18$ & 0.61 & 0.92 & nd & 26.01 & nd & nd & 12.37 & nd & 22.41 & nd & 26.98 & $4.40^{\mathrm{a}}$ & nd & 3.56 & 1.50 & nd & 1.24 & nd \\
\hline S19 & 4.88 & 8.60 & nd & 37.43 & nd & nd & 5.43 & nd & 20.33 & nd & 9.55 & 1.49 & nd & 7.19 & 1.51 & nd & $3.58^{\mathrm{a}}$ & nd \\
\hline S20 & 2.19 & $60.81^{a}$ & nd & 8.94 & 0.39 & nd & 1.26 & nd & 13.36 & nd & 11.94 & 0.08 & nd & 0.76 & 0.14 & nd & 0.13 & nd \\
\hline S21 & 0.08 & 1.59 & nd & 30.63 & 1.36 & 0.14 & 3.29 & nd & 28.00 & nd & 33.72 & 0.14 & nd & 0.81 & 0.13 & nd & 0.11 & nd \\
\hline & $17.47^{\mathrm{a}}$ & 1.97 & & 29.85 & & nd & 7.81 & & 7.56 & nd & 10.18 & 4.18 & nd & 18.57 & 1.63 & nd & 0.79 & nd \\
\hline S25 & 1.15 & 0.72 & nd & 15.01 & nd & nd & $\begin{array}{r}3.38 \\
11125\end{array}$ & nd & 2.14 & $17.74^{\text {a }}$ & 24.49 & 0.24 & nd & $\begin{array}{l}33.40 \\
0.32\end{array}$ & 0.64 & nd & $\begin{array}{l}1.09 \\
1.21\end{array}$ & nd \\
\hline S26 & 4.71 & 1.93 & nd & 28.57 & nd & nd & 11.35 & nd & 14.95 & nd & 26.61 & 0.44 & nd & 9.32 & 0.81 & nd & 1.31 & nd \\
\hline S27 & 2.62 & 0.95 & nd & 22.55 & nd & nd & 11.25 & nd & $41.64^{\mathrm{a}}$ & nd & 17.59 & nd & nd & 1.49 & 0.81 & nd & 1.11 & nd \\
\hline S28 & nd & 2.93 & nd & $47.85^{\mathrm{a}}$ & nd & nd & 11.39 & nd & 15.62 & nd & 7.74 & 3.65 & nd & 5.31 & 3.05 & nd & 2.45 & nd \\
\hline S29 & nd & 1.59 & nd & 42.71 & nd & nd & 10.67 & nd & 14.51 & nd & 10.90 & 3.09 & nd & 12.62 & 2.76 & nd & 1.14 & nd \\
\hline S30 & nd & 0.35 & nd & 14.29 & 0.63 & nd & 4.59 & nd & 21.11 & nd & 56.56 & 0.43 & nd & 1.54 & 0.26 & nd & 0.24 & nd \\
\hline S31 & 0.12 & 0.14 & nd & 5.53 & 0.30 & nd & 1.77 & nd & 32.97 & nd & 15.78 & 0.43 & $7.96^{\mathrm{a}}$ & 16.59 & 0.23 & $17.28^{\mathrm{a}}$ & 0.09 & $0.82^{\mathrm{a}}$ \\
\hline S32 & 7.95 & 3.44 & nd & 27.93 & nd & nd & 12.60 & nd & 4.47 & nd & 28.69 & 2.29 & nd & 5.99 & 2.39 & nd & $4.26^{\mathrm{a}}$ & nd \\
\hline S33 & 0.91 & $\begin{array}{l}1.83 \\
179\end{array}$ & nd & $\begin{array}{r}29.78 \\
31.47\end{array}$ & nd & nd & 10.11 & nd & 11.03 & nd & $\begin{array}{l}14.62 \\
32\end{array}$ & 1.52 & nd & 28.15 & 1.18 & nd & 0.87 & nd \\
\hline S34 & 3.85 & 1.79 & nd & 31.47 & nd & nd & 10.01 & nd & 7.49 & nd & 32.47 & nd & nd & 11.10 & 0.75 & nd & 1.07 & nd \\
\hline
\end{tabular}

Values ( $\%$ of total fatty acids) are the mean of six determina

detected. Sample numbers (S1-S34) correspond to Table 1. 


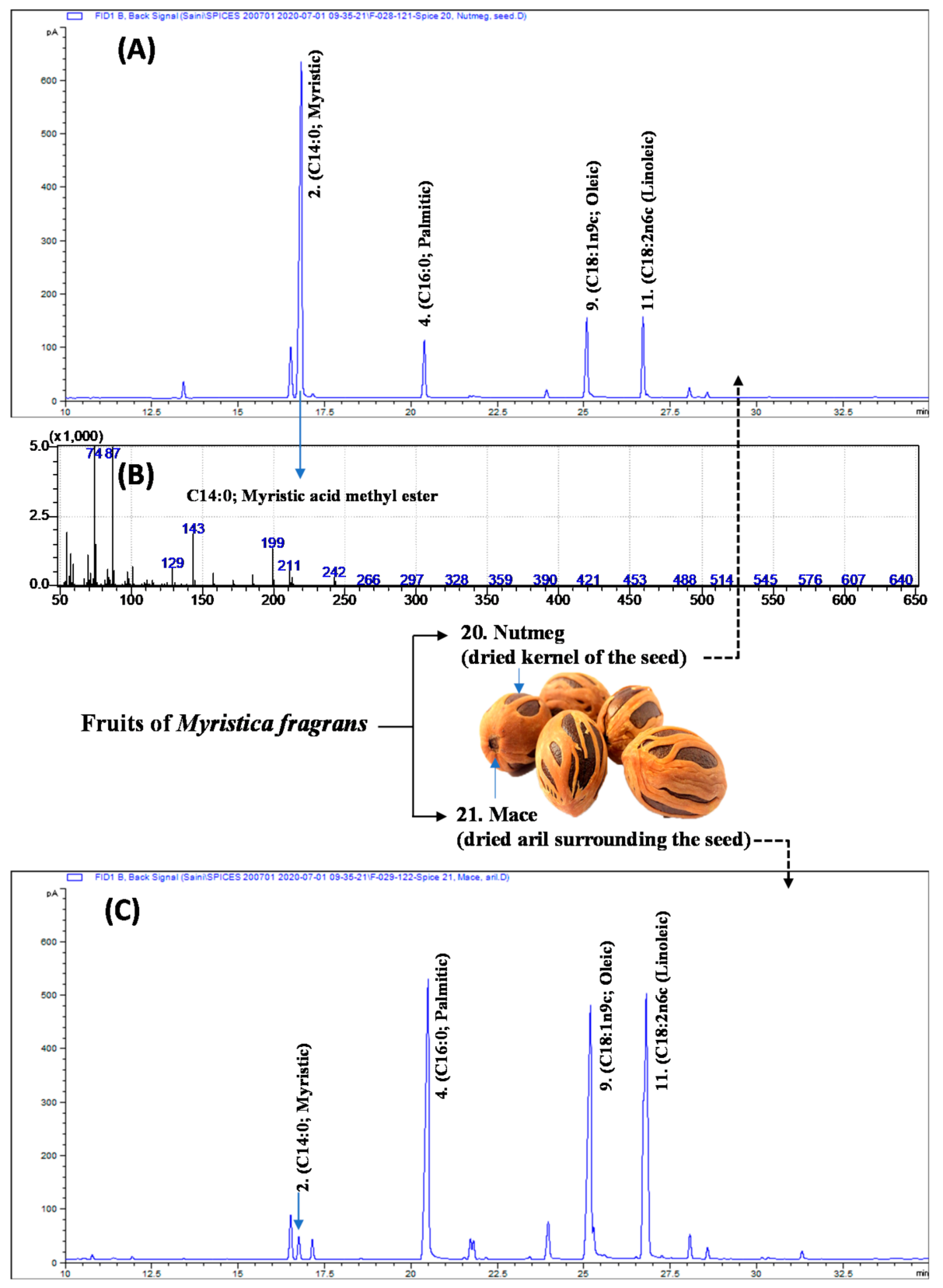

Figure 1. (A) The gas chromatography (GC)-flame ionization detection (FID) profiles of fatty acid methyl esters (FAMEs) of nutmeg. (B) The GC-mass spectrum of dominating fatty acid (myristic acid) from nutmeg. (C) The GC-FID profiles of FAMEs of mace. The numbers, 2, 4, 6, and 8 correspond to peak numbers illustrated in Table 1 .

In the present study, a substantial amount of erucic (C22:1n9; 17.3\%) and eicosenoic (20:1n9; gondoic acid; 8\%) acids were exclusively recorded in white mustard (Sinapis alba; syn Brassica alba) seeds. Similarly, a significant amount of petroselinic acid (C18:1n12c; an isomer of oleic acid) was recorded only in Apiaceae family seeds.

Among the studied 34 spices and herbs, total fatty acids were recorded to be in the range of 2.3 (galangal root) to $130.32 \mathrm{mg} / \mathrm{g}$ (mace). The odd chain fatty acid, pentadecanoic (C15:0) acid, was recorded as being a minor constituent $(1.18 \%)$ in the galangal root. Similarly, heptadecanoic (C17:0) was recorded at only $0.13-0.14 \%$ in cayenne pepper, allspice, and mace. In nutmeg (Myristica fragrans) seed hexane extract, Anaduaka et al. [19] reported a significant amount of (27\%) heptadecanoic (C17:0; margaric) acid. However, in the present study, heptadecanoic acid is not detected in nutmeg seeds. 


\subsection{Black Pepper and White Pepper}

Black pepper and white pepper are prepared from the fruits of Piper nigrum L., according to the harvesting time and inclusion of the outer skin. Black pepper is the dried immature but fully developed fruit, whereas white pepper consists of the mature fruit lacking the outer skin [20]. The fatty acid composition data of black and white pepper is scarce. In the present study, $28.57 \%, 14.95 \%, 26.61 \%$, and $9.32 \%$ of palmitic, oleic, linoleic, and $\alpha$-linolenic acid were recorded being in black pepper. In contrast, $22.55 \%, 41.64 \%$, $17.19 \%$, and $1.49 \%$ of palmitic, oleic, linoleic, and $\alpha$-linolenic was reported as being in white pepper (Table 2). These observations show that oleic acid increases significantly, whereas the palmitic, linoleic, and $\alpha$-linolenic acids decrease significantly during the maturation of pepper fruits.

\subsection{Nutmeg and Mace}

Nutmeg and mace spices are obtained from different parts of the same fruit of the nutmeg (Myristica fragrans; Myristicaceae) tree. Nutmeg is the dried kernel of the seed, whereas mace is the dried aril surrounding the seed [21]. Myristic acid's name is derived from Myristica fragrans, from which it was first isolated [22]. In the present study, myristic acid was $60.8 \%$ of total fatty acids in nutmeg, followed by oleic (C18:1n9c; $13.4 \%)$, linoleic (C18:2n6c; $11.9 \%)$, and palmitic (C16:0; 8.94\%) (Figure 1A). Surprisingly, in mace, linoleic acid was $33.7 \%$ of total fatty acids, followed by palmitic (30.6\%) and oleic (28.0\%). Myristic acid was only $1.59 \%$ of the total fatty acids (Figure 1C, Table 2). In the investigations of AlKhatib et al. [23], myristic acid was recorded as being $79.7 \%$ of the total fatty acids in nutmeg. Kozłowska et al. [24] analyzed the fatty acids composition of plant seeds, including anise, coriander, caraway, white mustard, and nutmeg. They reported dominance of oleic (56.5\%), palmitic $(18.29 \%)$, and linoleic $(13.6 \%)$ acids in nutmeg. These contrasting observations probably arose as these authors reported only above C16 fatty acids. Myristic acid is widely used in the food industry as a flavor ingredient. It is approved as a pharmaceutical excipient by the Food and Drug Administration (FDA) and declared generally recognized as safe (GRAS) by various regulators [25].

\subsection{Erucic Acid in White Mustard}

Mustard (Sinapis alba; syn Brassica alba) seeds are well known for the occurrence of a substantial amount of erucic and eicosenoic acid [24]. In the present study, white mustard seeds were found containing $17.3 \%$ and $8.0 \%$ of erucic and eicosenoic acid, respectively (Figure 2A, Table 2). High intake of erucic acid is considered harmful for cardiac health [26]. The panel on contaminants in the food chain established a tolerable daily intake (TDI) of $7 \mathrm{mg} / \mathrm{kg}$ body weight (BW) for erucic acid based on a no-observed adverse effect level (NOAEL) for myocardial lipidosis in rats and pigs [26]. Considering the $43 \mathrm{mg}$ of total fatty acids/g of white mustard seeds, consumption of $100 \mathrm{~g}$ of seeds may provide $7.31 \mathrm{mg}$ of erucic acid. The intake of erucic acid from white mustard used as food condiments in daily food preparations is far below the TDI and is safe for consumption. 


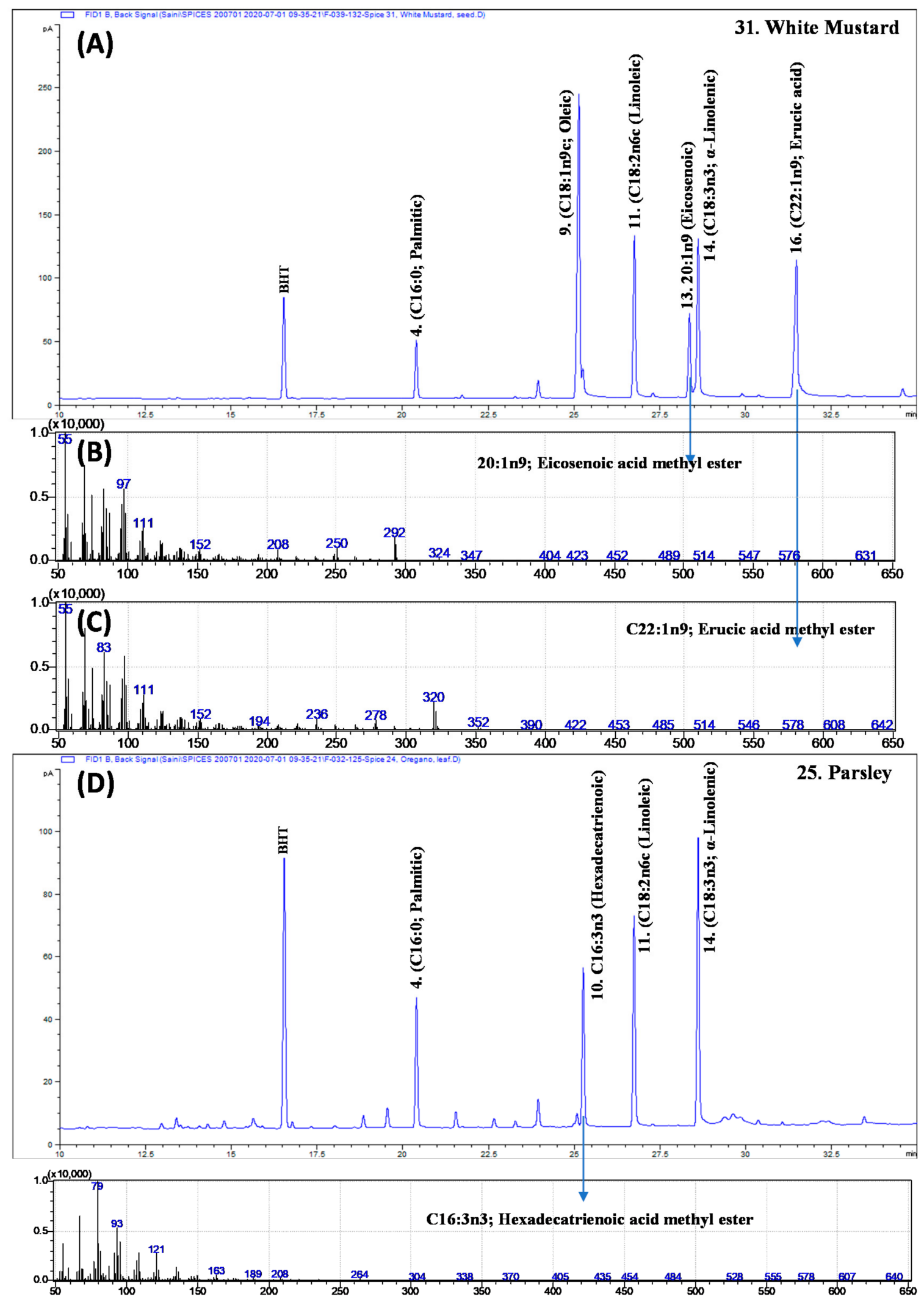

Figure 2. (A) The gas chromatography (GC)-flame ionization detection (FID) profiles of fatty acid methyl esters (FAMEs) of white mustard seeds. (B,C) The GC-mass spectrum of eicosenoic acid and erucic acid from white mustard seeds. (D) The GC-FID profiles of FAMEs of parsley leaves. The numbers, 4, 9, 10, 13, 14, and 16 correspond to peak numbers illustrated in Table 1. BHT: Butylated hydroxytoluene (A synthetic antioxidant used during lipid extraction). 
Petroselinic acid (C18:1n12c; an isomer of oleic acid) is the major component of the lipid constituent of Apiaceae family seeds [27,28]. In a previous study [27] of dill (Anethum graveolens) seeds, $87.2 \%$ of total fatty acids were composed of petroselinic acid. Similarly, in celery (Apium graveolens), coriander seeds (Coriandrum sativum), and fennel seeds (Foeniculum vulgare), petroselinic acid was recorded as being $56.1 \%, 72.8 \%$, and $31.32 \%$ of total fatty acids. In agreement with the present study, we have also recorded the $50.4 \%, 49.4 \%, 62.1 \%$, and $63.3 \%$ of petroselinic acid in dill, coriander celery, and fennel seeds, respectively (Table 2). And a similar high amount of petroselinic acid was reported to be in the seeds of other Apiaceae family plants, such as caraway (Carum carvi, $34.1 \%$ ) and cumin (Cuminum cyminum; 49.9\%). In seeds of different varieties of caraway, Reiter et al. [28] recorded 33.5-42.5\% of petroselinic acid, which is in agreement with the present study. Petroselinic acid possesses potent anti-inflammatory and antiaging properties by reducing the metabolites of arachidonic acid [29]. And owing to its anti-aging properties, petroselinic acid is widely used in cosmetics or dermatological compositions [29]. Surprisingly, petroselinic acid was not detected in herbs (leaves) of the Apiaceae family member parsley (Petroselinum crispum). In the parsley herb, hexadecatrienoic (C16:3n3) was reported to be $17.7 \%$ of the total fatty acids (Figure $2 \mathrm{D}$ ), whereas no other spices were found to contain this fatty acid. Parsley has been previously classified as a "16:3" plant owing to the presence of a significant amount of hexadecatrienoic acid in photosynthetic tissues, which is part of primitive lipid metabolism [30].

\subsection{Fat Quality Indices}

The present study is based on the fatty acid composition of 34 spices and herbs. We evaluated them for fat quality indices, including the $n-6 / n-3$ ratio, AI, TI, and h/H fatty acid ratios (Table 3). Among the studied spices and food condiments, the ratio of $n-6 / n-3$ PUFAs was found to be in the range of 0.36 (oregano) to 85.99 (cumin). In view of health benefits associated with the consumption of $n-6 / n-3$ PUFAs ratio of $0.5-2.0$ (nearest to 1:1), lipids obtained from leaf spices, including tarragon (0.76), bay leaf (1.33), basil (0.55), marjoram (0.75), parsley (0.48), white mustard (0.95), sage $(0.86)$, and thyme $(0.52)$ can be considered to be beneficial. In general, the high occurrence of $\alpha$-linolenic acids compared to linoleic acid is responsible for the low $n-6 / n-3$ ratio in leaves (photosynthetic tissue).

In view of the high risk of CVD and other chronic diseases that are associated with the dietary intake of SFAs [11], fats with a PUFAs/SFAs ratio lower than 0.45 are not advised for diet [31]. In the present study, PUFAs/SFAs ratios ranged from 0.17 (nutmeg) to 4.90 (cumin). Low PUFAs/SFAs ratios of 0.17 in nutmeg lipids are the result of the dominance of myristic acid (an SFA; Figure 1A), whereas in the case of cumin, linoleic acid is dominant over SFAs. In addition to the nutmeg, low PUFAs/SFAs ratios $(<0.44)$ were recorded from galangal root $(0.29)$, lemongrass $(0.24)$, rosemary $(0.28)$, and sage $(0.38)$ because of the occurrence of a substantial amount of palmitic acid (Figure S2).

Fats with lower $\mathrm{AI}$ and $\mathrm{TI}$ and higher ratios of $\mathrm{h} / \mathrm{H}$ fatty acids are recommended for minimizing the risk of CVD [32]. In the present study, a significant difference was recorded for $\mathrm{AI}$, TI values as well as $\mathrm{h} / \mathrm{H}$ fatty acids among the studied spices and herbs. The lowest significant values of the AI (0.06) and the highest ratios of $\mathrm{h} / \mathrm{H}$ fatty acids (17.0) were obtained from cumin seeds (Table 3, Figure 3), because of the presence of a low amount of atherogenic lauric, myristic, and palmitic fatty acids, and high amounts of hypocholesterolemic C18:1 MUFAs and PUFAs. Whereas the lowest significant values of TI (0.08) were recorded in white mustard, due to the low contents SFAs and high content of PUFAs.

Overall, based on a higher ratio of $\mathrm{h} / \mathrm{H}$ fatty acids and their lower $\mathrm{AI}$ and $\mathrm{TI}$ values, cumin, coriander, fennel, and dill spices have the healthiest fatty acid profiles (Figure 3). These spices belong to the Apiaceae family. White mustard also represents a higher ratio of $\mathrm{h} / \mathrm{H}$ fatty acids and lower values of $\mathrm{AI}$ and TI. However, it contains a substantial amount of erucic acid. 
In Figure 3, cumin, coriander, fennel, and dill spices top the fat quality indices, the ratio of $\mathrm{h} / \mathrm{H}$ fatty acids, $\mathrm{AI}$, and TI. However, the occurrence of a very low proportion of $\alpha$-linolenic acid (a $n-3$ PUFA; $0.35-0.85 \%$ ) and a fairly good amount of linoleic acid (a $n-6$ PUFA; $19.60-33.34 \%$ ) in these spices, give rise to the high ratio of $n-6 / n-3$ PUFAs (24.02-85.99), which is substantially higher than the recommended ratio of 1:1. Considering this, the culinary use of these spices can be recommended with $n-3$ PUFA rich components to obtain the overall $n-6 / n-3$ PUFAs ratio of 1:1.

Previously, we had analyzed the total phenolic contents (TPC) and antioxidant activities of 39 spices and herbs (including the 34 spices and herbs investigated in the present study) and found that cloves possess the highest antioxidant activities, followed by allspice, cinnamon, oregano, and marjoram [33]. The high antioxidant activities of these spices and herbs were probably the results of the richness of phenolic compounds, as the antioxidant activities showed a good correlation (0.835-0.966) with TPC. In contrast, in the present study, cumin, coriander, fennel, and dill spices showed the healthiest fatty acid profile among the 34 spices and herbs. These observations show that the selection of healthy spices and herbs may vary with nutrient requirements. Thus, in the present study, cumin, coriander, fennel, and dill spices are the recommendations based on the fatty acid profile. However, other spices and herbs might be richer in other health-beneficial dietary components.

Table 3. The fat quality indices of lipids of spices and herbs.

\begin{tabular}{|c|c|c|c|c|c|c|c|c|c|c|c|c|}
\hline $\begin{array}{c}\text { Sample } \\
\text { No }\end{array}$ & $\begin{array}{c}\text { Total FA } \\
\text { (mg/g } \\
\text { DW) }\end{array}$ & $\begin{array}{l}\text { Total } \\
\text { SFAs }\end{array}$ & $\begin{array}{c}\text { Total } \\
\text { MUFAs }\end{array}$ & $\begin{array}{l}\text { Total } \\
\text { PUFAs }\end{array}$ & $\begin{array}{c}\text { PUFAs: } \\
\text { SFAs }\end{array}$ & $\begin{array}{l}\text { PUFAs: } \\
\text { MUFAs }\end{array}$ & $\begin{array}{c}n-3 \\
\text { PUFA }\end{array}$ & $\begin{array}{c}n-6 \\
\text { PUFA }\end{array}$ & $n-6 / n-3$ & h/H & AI & TI \\
\hline S1 & $2.30^{\mathrm{b}}$ & 55.75 & 28.21 & 16.04 & 0.29 & 0.57 & 2.45 & 13.59 & 5.55 & 1.13 & 0.95 & 1.82 \\
\hline S2 & 23.30 & 12.70 & 65.97 & 21.34 & 1.68 & $0.32^{b}$ & 0.85 & 20.49 & 24.02 & 8.22 & 0.15 & 0.24 \\
\hline S3 & 27.60 & 14.02 & 57.11 & 28.88 & 2.06 & 0.51 & 1.32 & 27.55 & 20.82 & 7.45 & 0.15 & 0.29 \\
\hline S4 & 8.30 & 41.83 & $2.23^{\mathrm{b}}$ & 55.94 & 1.34 & 25.13 & 31.84 & 24.10 & $0.76^{b}$ & 1.68 & 0.75 & 0.28 \\
\hline S5 & 120.83 & 23.06 & 12.96 & 63.99 & 2.78 & 4.94 & 2.53 & 61.46 & 24.30 & 3.92 & 0.29 & 0.49 \\
\hline S6 & 48.72 & 24.07 & 13.54 & 62.40 & 2.59 & 4.61 & 2.75 & 59.65 & 21.71 & 3.72 & 0.31 & 0.51 \\
\hline S7 & 42.00 & 31.29 & 40.04 & 28.67 & 0.92 & 0.72 & 0.68 & 27.99 & 41.12 & 2.57 & 0.52 & 0.81 \\
\hline S8 & 103.38 & 19.90 & 45.93 & 34.17 & 1.72 & 0.74 & $0.47^{b}$ & 33.70 & 71.19 & 4.94 & 0.60 & 0.46 \\
\hline S9 & 2.78 & 45.73 & 23.25 & 31.03 & 0.68 & 1.33 & 4.04 & 26.99 & 6.68 & 1.52 & 0.76 & 1.16 \\
\hline S10 & 57.06 & 9.30 & $69.49^{a}$ & 21.21 & 2.28 & $0.31^{b}$ & $0.35^{b}$ & 20.85 & 58.96 & 12.12 & 0.10 & 0.19 \\
\hline S11 & 36.37 & $6.88^{b}$ & 59.39 & 33.73 & $4.90^{\mathrm{a}}$ & 0.57 & $0.39^{b}$ & 33.34 & $85.99^{a}$ & $17.01^{\mathrm{a}}$ & $0.06^{b}$ & 0.14 \\
\hline S12 & 7.01 & 17.39 & 5.24 & $77.36^{a}$ & 4.45 & 14.75 & 4.50 & $72.86^{a}$ & 16.20 & 5.96 & 0.18 & 0.26 \\
\hline S13 & 2.75 & $75.80^{a}$ & 6.20 & 17.99 & 0.24 & 2.90 & 5.70 & 12.29 & 2.16 & $0.43^{b}$ & 2.66 & 2.24 \\
\hline S14 & 8.87 & 38.10 & 43.39 & 18.50 & 0.49 & $0.43^{b}$ & 3.44 & 15.07 & 4.38 & 1.80 & 0.58 & 0.92 \\
\hline S15 & 53.18 & 9.45 & $70.42^{a}$ & 20.13 & 2.13 & $0.29^{b}$ & $0.53^{b}$ & 19.60 & 37.30 & 11.47 & 0.09 & 0.19 \\
\hline S16 & 29.96 & 26.11 & 33.92 & 39.98 & 1.53 & 1.18 & 0.71 & 39.27 & 55.10 & 3.35 & 0.31 & 0.63 \\
\hline S17 & 22.49 & 43.98 & 13.90 & 42.11 & 0.96 & 3.03 & 2.53 & 39.58 & 15.62 & 3.85 & 0.28 & 1.21 \\
\hline S18 & 5.98 & 47.05 & 22.41 & 30.54 & 0.65 & 1.36 & 3.56 & 26.98 & 7.58 & 1.92 & 0.57 & 1.11 \\
\hline S19 & 5.39 & 62.92 & 20.33 & 16.74 & 0.27 & 0.82 & 7.19 & 9.55 & 1.33 & 0.73 & 2.07 & 1.38 \\
\hline $\mathrm{S} 20$ & 61.04 & 73.56 & 13.74 & $12.70^{b}$ & $0.17^{b}$ & 0.92 & 0.76 & 11.94 & 15.73 & $0.36^{\mathrm{b}}$ & $9.62^{\mathrm{a}}$ & $4.68^{a}$ \\
\hline S21 & $130.32^{a}$ & 36.12 & 29.36 & 34.53 & 0.96 & 1.18 & 0.81 & 33.72 & 41.69 & 1.94 & 0.58 & 1.04 \\
\hline $\mathrm{S} 22$ & 6.23 & 63.69 & 7.56 & 28.75 & 0.45 & 3.80 & 18.57 & 10.18 & $0.55^{b}$ & 0.74 & 1.52 & 0.60 \\
\hline $\mathrm{S} 23$ & 8.09 & 34.48 & 33.65 & 31.87 & 0.92 & 0.95 & 18.23 & 13.64 & $0.75^{b}$ & 2.72 & 0.43 & 0.36 \\
\hline S24 & 8.84 & 46.01 & 6.42 & 47.57 & 1.03 & 7.41 & 35.08 & 12.49 & $0.36^{b}$ & 1.57 & 0.24 & 0.32 \\
\hline $\mathrm{S} 25$ & 14.05 & 22.23 & $2.14^{\mathrm{b}}$ & 75.63 & 3.40 & $35.37^{\mathrm{a}}$ & $51.14^{\mathrm{a}}$ & 24.49 & $0.48^{b}$ & 4.61 & 0.78 & 0.11 \\
\hline S26 & 5.38 & 49.12 & 14.95 & 35.93 & 0.73 & 2.40 & 9.32 & 26.61 & 2.86 & 1.45 & 0.81 & 0.85 \\
\hline S27 & 3.75 & 39.28 & 41.64 & 19.08 & 0.49 & 0.46 & 1.49 & 17.59 & 11.80 & 2.32 & 0.48 & 1.02 \\
\hline S28 & 4.38 & 71.32 & 15.62 & $13.06^{b}$ & $0.18^{b}$ & 0.84 & 5.31 & $7.74^{b}$ & 1.46 & 0.56 & 2.08 & 2.20 \\
\hline S29 & 6.74 & 61.96 & 14.51 & 23.53 & 0.38 & 1.62 & 12.62 & 10.90 & $0.86^{b}$ & 0.86 & 1.29 & 1.06 \\
\hline S30 & 32.31 & 20.16 & 21.74 & 58.10 & 2.88 & 2.67 & 1.54 & 56.56 & 36.78 & 5.41 & 0.20 & 0.44 \\
\hline S31 & 43.00 & 8.30 & 59.33 & 32.37 & 3.90 & 0.55 & 16.59 & 15.78 & $0.95^{b}$ & 11.29 & $0.07^{b}$ & $0.08^{b}$ \\
\hline S32 & 7.13 & 60.86 & 4.47 & 34.68 & 0.57 & 7.76 & 5.99 & 28.69 & 4.79 & 1.00 & 1.27 & 1.27 \\
\hline S33 & 5.95 & 46.20 & 11.03 & 42.77 & 0.93 & 3.88 & 28.15 & 14.62 & $0.52^{b}$ & 1.65 & 0.71 & 0.42 \\
\hline S34 & 5.26 & 48.94 & 7.49 & 43.57 & 0.89 & 5.81 & 11.10 & 32.47 & 2.93 & 1.38 & 0.83 & 0.81 \\
\hline
\end{tabular}

Values are the mean of six determinations. PUFAs: total polyunsaturated fatty acids; MUFAs: total monounsaturated fatty acids; SFAs: total saturated fatty acids; AI: atherogenic index; and TI: thrombogenic index; $\mathrm{h} / \mathrm{H}$ : ratios of hypocholesterolemic (h)/hypercholesterolemic $(\mathrm{H})$ fatty acids. The letters a and b within a column represent the highest and lowest significant $(p<0.05)$ values, respectively. Sample numbers (S1-S34) correspond to the Table 1. 
(A)

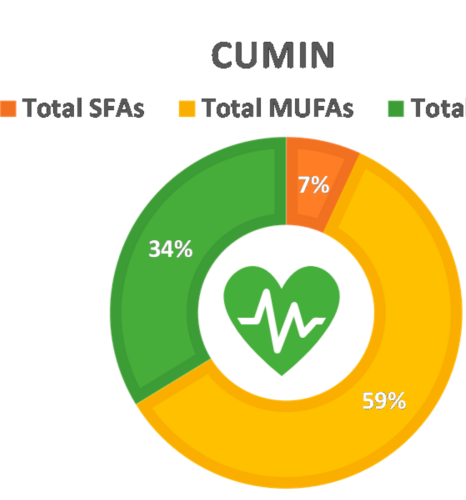

(B)

\begin{tabular}{|c|c|}
\hline$h / H$ & \\
\hline \multicolumn{2}{|r|}{ Cumin, 17.0} \\
\hline & Coriander, 12.1 \\
\hline & Fennel, 11.5 \\
\hline & White Mustard, 11.3 \\
\hline & Dill, 8.2 \\
\hline & Celery, 7.45 \\
\hline & Turmeric, 5.96 \\
\hline & Pink Peppercorn, 5.41 \\
\hline & Caraway, 4.94 \\
\hline & Parsley, 4.61 \\
\hline & Cayenne Pepper, 3.92 \\
\hline & Allspice, 3.85 \\
\hline & Pepperoncini, 3.72 \\
\hline & Star Anise, 3.35 \\
\hline & Marjoram, 2.72 \\
\hline & Hot chili pepper, 2.57 \\
\hline & White Pepper, 2.32 \\
\hline & Mace, 1.94 \\
\hline & Juniper berry, 1.92 \\
\hline & Cardamom, 1.80 \\
\hline & Tarragon, 1.68 \\
\hline & Thyme, 1.65 \\
\hline & Oregano, 1.57 \\
\hline & Cinnamon, 1.52 \\
\hline & Black Pepper, 1.45 \\
\hline & Ginger, 1.38 \\
\hline & Galgal root, 1.13 \\
\hline & Clove, 1.00 \\
\hline & Sage, 0.86 \\
\hline & Basil, 0.74 \\
\hline & Bay leaf, 0.73 \\
\hline & Rosemary, 0.56 \\
\hline & Lemon grass, 0.43 \\
\hline & Nutmeg, 0.36 \\
\hline
\end{tabular}

\section{Al}

Cumin, 0.06 White Mustard, 0.07 Fennel, 0.09 Coriander, $\mathbf{0 . 1 0}$ Celery, 0.15 Dill, 0.15 Turmeric, 0.18 Pink, Peppercorn, 0.20 Parsley, 0.24 Allspice, 0.28 Cayenne Pepper, 0.29 Star Anise, 0.31 Pepperoncini, 0.31 Marjoram, 0.43 White Pepper, $\mathbf{0 . 4 8}$ Hot chili pepper, 0.52 Juniper berry, 0.57 Cardamom, 0.58 Mace, 0.58

Caraway, 0.60 Thyme, 0.71 Tarragon, 0.75 Cinnamon, 0.76 Oregano, 0.78 Black Pepper, 0.81 Ginger, 0.83 Galgal root, 0.95 Clove, 1.27 Sage, 1.29 Basil, 1.52

Bay leaf, 2.07

Rosemary, 2.08 Lemon grass, 2.66 Nutmeg, 9.62
NUTMEG

Total SFAs $\approx$ Total MUFAs $\approx$ Total PUFAs

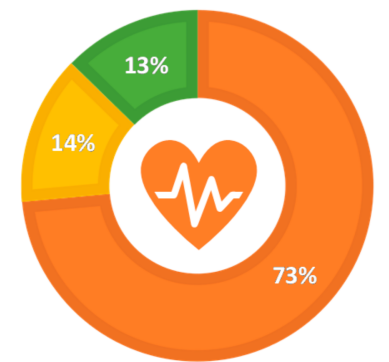

TI

White Mustard, 0.08 Parsley, 0.11 Cumin, 0.14 Fennel, 0.19

Coriander seed, 0.19 Dill, 0.24

Turmeric, 0.26 Tarragon, 0.28 Celery, 0.29

Oregano, 0.32 Marjoram, 0.36 Thyme, 0.42

Pink Peppercorn, 0.44 Caraway, 0.46

Cayenne Pepper, 0.49

Pepperoncini, 0.51 Basil, 0.60 Star Anise, 0.63 Hot chili pepper, 0.81 Ginger, 0.81 Black Pepper, 0.85 Cardamom, 0.92 White Pepper, 1.02 Mace, 1.04 Sage, 1.06 Juniper berry, 1.11 Cinnamon, 1.16 Allspice, 1.21 Clove, 1.27 Bay leaf, 1.38 Galgal root, 1.82 Rosemary, 2.20

Lemon grass, 2.24 Nutmeg, 4.68

Figure 3. (A) Illustrations showing the high content of healthy monounsaturated (MUFAs) and polyunsaturated fatty acids (PUFAs) in cumin, compared to low contents of MUFAs and PUFAs, and high contents of saturated fatty acids (SFAs) in nutmeg. (B) Arrangements of studied spices and herbs in ascending/descending order according to the fat quality indices of the ratio of hypocholesterolemic (h)/hypercholesterolemic fatty acids, atherogenic index (AI), and thrombogenic index (TI). 


\section{Conclusions}

Spices belonging to Apiaceae family plants (cumin, coriander, fennel, and dill) are an exceptionally rich source of monounsaturated fatty acids (MUFAs) in the form of petroselinic acid, a good amount of polyunsaturated fatty acids (PUFAs; linoleic acid), and a small amount of saturated fatty acids. And, with high proportions of MUFAs and PUFAs, the Apiaceae family spices top the fat quality indices, particularly in terms of a higher ratio of hypocholesterolemic/hypercholesterolemic fatty acids, and lower values of the atherogenic index and the thrombogenic index (Figure 3).

Supplementary Materials: The following are available online at https:/ /Www.mdpi.com/article/ 10.3390/foods10040854/s1, Figure S1: (A) The gas chromatography (GC)-flame ionization detection (FID) profiles of fatty acid methyl esters (FAMEs) of cardamom. (B) The GC-mass spectrum of dominating fatty acid (Palmitic acid); Figure S2. (A-C) The gas chromatography (GC)-flame ionization detection (FID) profiles of fatty acid methyl esters (FAMEs) of lemongrass, rosemary, and Sage. The GC-mass spectrum of dominating fatty acid (Palmitic acid). The numbers, 4, 7, 9, 11, and 14 correspond to peak numbers illustrated in Table 1. BHT: Butylated hydroxytoluene (A synthetic antioxidant used during lipid extraction).

Author Contributions: Conceptualization, R.K.S. and A.D.A.; methodology, R.K.S. and A.D.A.; software, R.K.S. and A.D.A.; validation, R.K.S. and A.D.A. and Y.-S.K.; formal analysis, R.K.S.; investigation, R.K.S.; resources, Y.-S.K.; data curation, R.K.S. and A.D.A.; writing-original draft preparation, R.K.S.; writing—review and editing, A.D.A. and Y.-S.K.; visualization, Y.-S.K.; supervision, Y.-S.K.; project administration, R.K.S.; funding acquisition, R.K.S. All authors have read and agreed to the published version of the manuscript.

Funding: This paper was supported by the KU Research Professor Program of Konkuk University, Seoul, Republic of Korea and "The APC was supported by Konkuk University research fund (2021A0190061)".

Acknowledgments: This paper was supported by the KU Research Professor Program of Konkuk University, Seoul, Korea.

Conflicts of Interest: The authors declare no conflict of interest.

\section{References}

1. Rubió, L.; Motilva, M.-J.; Romero, M.-P. Recent Advances in Biologically Active Compounds in Herbs and Spices: A Review of the Most Effective Antioxidant and Anti-Inflammatory Active Principles. Crit. Rev. Food Sci. Nutr. 2013, 53, 943-953. [CrossRef] [PubMed]

2. Martínez-Graciá, C.; González-Bermúdez, C.A.; Cabellero-Valcárcel, A.M.; Santaella-Pascual, M.; Frontela-Saseta, C. Use of herbs and spices for food preservation: Advantages and limitations. Curr. Opin. Food Sci. 2015, 6, 38-43. [CrossRef]

3. Shahidi, F.; Ambigaipalan, P. Phenolics and polyphenolics in foods, beverages and spices: Antioxidant activity and health effects-A review. J. Funct. Foods 2015, 18, 820-897. [CrossRef]

4. Viuda-Martos, M.; Ruiz-Navajas, Y.; Fernández-López, J.; Pérez-Álvarez, J. Spices as functional foods. Crit. Rev. Food Sci. Nutr. 2010, 51, 13-28. [CrossRef]

5. Jiang, T.A. Health Benefits of Culinary Herbs and Spices. J. AOAC Int. 2019, 102, 395-411. [CrossRef]

6. Alasvand, S.; Bridges, W.; Haley-Zitlin, V. Efficacy of Common Spices on Improving Serum Lipids in Individuals with Type 2 Diabetes: Systematic Review and Meta-Analysis of Clinical Trials. Curr. Dev. Nutr. 2020, 4, 1. [CrossRef]

7. Yu, L.; Choe, U.; Li, Y.; Zhang, Y. Oils from fruit, spice, and herb seeds. Bailey Ind. Oil Fat Prod. 2005, 1-35. [CrossRef]

8. Saini, R.K.; Keum, Y.S. Omega-3 and omega- 6 polyunsaturated fatty acids: Dietary sources, metabolism, and significance-A review. Life Sci. 2018, 203, 255-267. [CrossRef]

9. Harnack, K.; Andersen, G.; Somoza, V. Quantitation of alpha-linolenic acid elongation to eicosapentaenoic and docosahexaenoic acid as affected by the ratio of n6/n3 fatty acids. Nutr. Metab. 2009, 6, 8. [CrossRef]

10. Simopoulos, A.P. Evolutionary aspects of the dietary omega-6/omega-3 fatty acid Ratio: Medical implications. In Evolutionary Thinking in Medicine; Springer: Berlin/Heidelberg, Germany, 2016; pp. 119-134.

11. Briggs, M.; Petersen, K.; Kris-Etherton, P. Saturated Fatty Acids and Cardiovascular Disease: Replacements for Saturated Fat to Reduce Cardiovascular Risk. Healthcare 2017, 5, 29. [CrossRef]

12. Cruz, R.; Casal, S.; Mendes, E.; Costa, A.; Santos, C.; Morais, S. Validation of a Single-Extraction Procedure for Sequential Analysis of Vitamin E, Cholesterol, Fatty Acids, and Total Fat in Seafood. Food Anal. Methods 2013, 6, 1196-1204. [CrossRef]

13. Saini, R.K.; Mahomoodally, M.F.; Sadeer, N.B.; Keum, Y.S.; Rr Rengasamy, K. Characterization of nutritionally important lipophilic constituents from brown kelp Ecklonia radiata (C. Ag.) J. Agardh. Food Chem. 2021, 340. [CrossRef] 
14. Saini, R.K.; Rengasamy, K.R.R.; Ko, E.Y.; Kim, J.T.; Keum, Y.S. Korean Maize Hybrids Present Significant Diversity in Fatty Acid Composition: An Investigation to Identify PUFA-Rich Hybrids for a Healthy Diet. Front. Nutr. 2020, 7. [CrossRef]

15. Saini, R.K.; Keum, Y.-S.; Rengasamy, K.R. Profiling of nutritionally important metabolites in green/red and green perilla (Perilla frutescens Britt.) cultivars: A comparative study. Ind. Crop Prod. 2020, 151, 112441. [CrossRef]

16. Chen, J.; Liu, H. Nutritional Indices for Assessing Fatty Acids: A Mini-Review. Int. J. Mol. Sci. 2020, 21, 5695. [CrossRef]

17. Parry, J.W.; Cheng, Z.; Moore, J.; Yu, L.L. Fatty Acid Composition, Antioxidant Properties, and Antiproliferative Capacity of Selected Cold-Pressed Seed Flours. J. Am. Oil Chem. Soc. 2008, 85, 457-464. [CrossRef]

18. Parry, J.; Hao, Z.; Luther, M.; Su, L.; Zhou, K.; Yu, L. Characterization of cold-pressed onion, parsley, cardamom, mullein, roasted pumpkin, and milk thistle seed oils. J. Am. Oil Chem. Soc. 2006, 83, 847-854. [CrossRef]

19. Anaduaka, E.G.; Uchendu, N.O.; Ezeanyika, L.U.S. Mineral, amino acid and fatty acid evaluations of Myristica fragrans seeds extracts. Sci. Afr. 2020, 10, e00567. [CrossRef]

20. Lee, J.-G.; Chae, Y.; Shin, Y.; Kim, Y.-J. Chemical composition and antioxidant capacity of black pepper pericarp. Appl. Biol. Chem. 2020, 63. [CrossRef]

21. Rema, J.; Krishnamoorthy, B. 22-Nutmeg and mace. In Handbook of Herbs and Spices, 2nd ed.; Peter, K.V., Ed.; Woodhead Publishing: Abington, UK, 2012; pp. 399-416. [CrossRef]

22. Playfair, L. XX. On a new fat acid in the butter of nutmegs. Lond. Edinb. Dublin Philos. Mag. J. Sci. 1841, 18, 102-113. [CrossRef]

23. Al-Khatib, I.M.H.; Hanifa Moursi, S.A.; Mehdi, A.W.R.; Al-Shabibi, M.M. Gas-liquid chromatographic determination of fatty acids and sterols of selected Iraqi foods. J. Food Compos. Anal. 1987, 1, 59-64. [CrossRef]

24. Kozłowska, M.; Gruczyńska, E.; Ścibisz, I.; Rudzińska, M. Fatty acids and sterols composition, and antioxidant activity of oils extracted from plant seeds. Food Chem. 2016, 213, 450-456. [CrossRef]

25. Burdock, G.A.; Carabin, I.G. Safety assessment of myristic acid as a food ingredient. Food Chem. Toxicol. 2007, 45, 517-529. [CrossRef]

26. Knutsen, H.K.; Alexander, J.; Barregård, L.; Bignami, M.; Brüschweiler, B.; Ceccatelli, S.; Dinovi, M.; Edler, L.; Grasl-Kraupp, B.; Hogstrand, C.; et al. Erucic acid in feed and food. EFSA J. 2016, 14. [CrossRef]

27. Ksouda, G.; Hajji, M.; Sellimi, S.; Merlier, F.; Falcimaigne-Cordin, A.; Nasri, M.; Thomasset, B. A systematic comparison of 25 Tunisian plant species based on oil and phenolic contents, fatty acid composition and antioxidant activity. Ind. Crop Prod. 2018, 123, 768-778. [CrossRef]

28. Reiter, B.; Lechner, M.; Lorbeer, E. The fatty acid profiles-Including petroselinic and cis-vaccenic acid-of different Umbelliferae seed oils. Lipid/Fett 1998, 100, 498-502. [CrossRef]

29. Alaluf, S.; Green, M.; Powell, J.; Rogers, J.; Watkinson, A.; Cain, F.; Hu, H.; Rawlings, A. Petroselinic Acid and Its Use in Food. U.S. Patent No. 6,365,175 B1, 2 April 2002.

30. Mongrand, S.; Bessoule, J.-J.; Cabantous, F.; Cassagne, C. The C16:3 \C18:3 fatty acid balance in photosynthetic tissues from 468 plant species. Phytochemistry 1998, 49, 1049-1064. [CrossRef]

31. Wołoszyn, J.; Haraf, G.; Okruszek, A.; Wereńska, M.; Goluch, Z.; Teleszko, M. Fatty acid profiles and health lipid indices in the breast muscles of local Polish goose varieties. Poult. Sci. 2020, 99, 1216-1224. [CrossRef]

32. Ulbricht, T.L.V.; Southgate, D.A.T. Coronary heart disease: Seven dietary factors. Lancet 1991, 338, 985-992. [CrossRef]

33. Assefa, A.D.; Keum, Y.S.; Saini, R.K. A comprehensive study of polyphenols contents and antioxidant potential of 39 widely used spices and food condiments. J. Food Meas. Charact. 2018, 12, 1548-1555. [CrossRef] 